AWEJ for Translation \& Literary Studies, Volume3, Number4. October 2019

DOI: http://dx.doi.org/10.24093/awejtls/vol3no4.2

Pp. 19-23

\title{
Strategies of Desire in Nejoud Al-Yagout's Poetry
}

\author{
Shahd Alshammari \\ English Department, Gulf University for Science and Technology \\ Kuwait
}

\begin{abstract}
This paper considers the ways by which language is used within the context of poetic expression. Kuwaiti author Nejoud Al-Yagout experiments with the usage of English and Italian in her poetry collections This is An Imprint (2015) and Ounces of Oneness (2016). The work, the author argues, is essentially a desire for an ultimate dissolving of boundaries. Western thought relies heavily on binaries and dichotomies that are set in hierarchies. Reading Al-Yagout's work as a translingual writer enables us to shift between borders of language and culture. Throughout a close textual analysis of her poetry, we arrive at the premise that Al-Yagout's work is not only undefined by language and culture, but it is also limitless in its expansive call for a dissolution of boundaries. The speaker is almost always androgynous, to use Virginia Woolf's term, and searches for a deeper understanding of herself within the borders of society. The author of this paper argues that AlYagout's multiplicity of voice arrives instead within the semiotic chora, and yet, the chora in AlYagout's work is not the maternal, but rather, the Divine.
\end{abstract}

Keywords: Arab, Anglophone, desire, Gulf, Nejoud Al-Yagout, poetry, strategies, women, Kuwait

Cites as: Alshammari, S. (2019). Strategies of Desire in Nejoud Al-Yagout's Poetry. Arab World English Journal for Translation \& Literary Studies3 (4) 19-23.

DOI: http://dx.doi.org/10.24093/awejtls/vol3no4.2 